\title{
Hubungan Iklim dengan Kejadian Demam Berdarah Dengue (DBD)
}

\section{The Relationship between Climate with Dengue Hemorrhagic Fever (DHF)}

\author{
Irma $^{1}$, Yusuf Sabilu ${ }^{2}$, Harleli ${ }^{3}$, Swaidatul Masluhiya $\mathbf{A F}^{4}$ \\ ${ }^{1,2,3}$ Fakultas Kesehatan Masyarakat Universitas Halu Oleo, Kendari, Indonesia \\ ${ }^{4}$ Fakultas Ilmu Kesehatan Universitas Tribhuwana Tunggadewi, Malang, Indonesia
}

\section{ARTICLE INFO}

\section{Article history}

Received date $05 \mathrm{Jul} 2021$

Revised date

09 Jul 2021

Accepted date

20 Aug 2021

\section{Keywords:}

DHF;

Air temperature;

Rainfall.

Kata kunci:

DBD;

Suhu udara;

Curah hujan.

\author{
ABSTRACT/ ABSTRAK
}

\begin{abstract}
Dengue Hemorrhagic Fever (DHF) is a serious health problem, especially in tropical countries including east Indonesia. DHF cases in Bau-Bau City in the last three years have shown a significant increasing trend. In 2017 the IR DHF in Bau-Bau was 62,6 per 100.000 population, in 2018 the IR rate was 67,4 per 100,000 population, and the CFR rate was $1 \%$, and in 2019 the IR DHF was 94,9 per 100,000 population with the CFR increasing to $1,3 \%$. The purpose of this study was to determine the relationship between rainfall and humidity with the incidence of DHF. This study is an ecological study using secondary data on DHF and climate which were collected retrospectively. Data on dengue fever for 566 cases were taken from the Health Office of Bau-Bau City and data on climate were taken from the Meteorology, Climatology and Geophysics Agency (BMKG) Meteorological Station Class II Betoambari Bau-Bau City. The analysis was carried out univariate and bivariate with the Spearman correlation test at 0,05 to determine the relationship between rainfall and humidity with the incidence of DHF. The results of the Spearman correlation test of rainfall with the incidence of DHF obtained a value of $=0,006$ and $r=0,35$ and air temperature with the incidence of DHF with a value of $=0,000$ and a value of $r=0,576$. Climatic factors, namely rainfall and air temperature, are associated with the incidence of dengue fever in Bau-Bau City, Southeast Sulawesi.
\end{abstract}

Corresponding Author:

Irma

Fakultas Kesehatan Masyarakat, Universitas Halu Oleo, Kendari, Indonesia

Email: irmankedtrop15@gmail.com

\section{PENDAHULUAN}

Demam beradarah dengue (DBD) adalah penyakit yang disebabkan oleh virus dengue yang ditularkan melalui nyamuk. Dalam 50 tahun terakhir, insiden DBD meningkat 30 kali lipat dengan penyebaran yang semakin meluas ke berbagai negara terutama pada negara-negara beriklim tropik (WHO, 2011). Sekitar 50 juta populasi dunia terinfeksi demam berdarah dengue setiap tahunnya dan sekitar 5 miliar orang tinggal di negara yang endemik DBD (Scott, 
2009). Di negara-negara Asia Timur dan Amerika Latin DBD mengalami peningkatan dan penyebaran baik pada daerah perkotaan, pinggiran kota maupun pada daerah pedesaan (Zambrano, et al., 2012; Taylor, 2016).

Curah hujan merupakan salah satu faktor penentu kejadian demam berdarah dengue (DBD) selain faktor suhu dan suhu, densitas virus, serta herd immunity (Halstead and Deen, 2002). Di sebagian besar negara, epidemi dengue dilaporkan terjadi selama musim peralihan antara musim hujan dan musim panas karena kondisi ini mendukung pertumbuhan nyamuk (Halstead and Deen, 2002). Diaz-Qujiano, et al. (2008 dalam Iriani 2016) melaporkan terdapat asosiasi yang bermakna antara rerata curah hujan dalam lima minggu dan peningkatan jumlah kasus DBD di Bogota Columbia (Halstead and Deen, 2002; Iriani, 2016).

Perubahan iklim dunia dapat memberikan pengaruh terhadap musim penularan dan area sebaran penyakit DBD di wilayah regional AsiaPasifik. Hal tersebut berdasarkan studi literasi tentang hubungan perubahan iklim dengan DBD di beberapa negara, yaitu Thailand, Taiwan, India, Indonesia, China, Singapura, dan Australia (Banu et al., 2011).

Kasus DBD juga telah menyebar di beberapa daerah kabupaten/kota di Provinsi Sulawesi Tenggara dan pada tahun 2016 jumlah kasus DBD di Sulawesi Tenggara sebanyak 3.433, tahun 2017 sebanyak 817 kasus, pada tahun 2018 sebanyak 655 kasus dan pada tahun 2019 yaitu sebanyak 1.493 kasus (Sultra D.K.P, 2020). Salah satu wilayah kabupaten/kota dengan kasus DBD tertinggi setelah ibu kota provinsi Sulawesi Tenggara adalah Kota Bau-Bau. Kasus DBD di Kota Bau-Bau dalam tiga tahun terakhir menunjukkan tren peningkatan yang cukup signifikan. Pada tahun 2017 IR DBD di Kota Bau-Bau sebesar 62,6 per 100.000 penduduk, tahun 2018 angka IR sebesar 67,4 per 100.000 penduduk dan angka CFR 1\%, dan tahun 2019 IR DBD sebesar 94,9 per 100.000 penduduk dengan CFR naik menjadi $1,3 \%$.

Beberapa penelitian menunjukan bahwa ada korelasi antara curah hujan dengan peningkatan kasus DBD misalnya penelitian yang dilakukan oleh Mishra \& Kumar (2005) menemukan bahwa ada hubungan antara tingginya rata-rata curah hujan di beberapa wialayah di Binhar India berkaitan dengan peningkatan kasus DBD. Demikian juga penelitian dari Zambrano (2010) yang menemukan fakta bahwa ada hubungan yang signifikan antara peningkatan jumlah penderita DBD dengan tingginya curah hujan. Penelitian yang sejenis juga pernah dilakukan oleh Iriani (2016) di Kota Palembang yang menemmukan bahwa ada hubungan yang signifikan antara tingginya curah hujan dengan peningkatan kasus DBD. Penelitian ini bertujuan untuk melihat hubungan antara curah hujan dan kelembaban dengan peningkatan kasus DBD di Kota Bau-Bau berdasarkan agregat data DBD, curah hujan dan suhu udara per bulan selama tahun 2015 sampai dengan tahun 2019 (Mishra and Kumar, 2011).

\section{METODE}

Desain penelitian ini adalah studi ekologi yang memakai data agregat. Unit analisis penelitian ini adalah waktu per bulan selama lima tahun. Penelitian ini menggunakan data sekunder tentang kasus DBD sebanyak 566 kasus yang diamati setiap bulannya selama 5 tahun, dari tahun 2015 sampai dengan tahun 2019. Data DBD diperoleh dari Dinas Kesehatan Kota Bau-Bau dan data curah hujan dan suhu udara per bulan selama lima tahun yang di peroleh dari Badan Meteorologi, Klimatologi, dan Geofisika (BMKG) Stasiun Meteorologi Kelas II Betoambari Kota Bau-Bau. Penelitian ini telah mendapatkan kelaikan etik dari Komisi Etik Penelitian Kesehatan Fakultas Kedokteran Universitas Halu Oleo dengan Nomor. 065/UN29.17.1.3/ETIK/2020.

Analisis penelitian diawali analisis univariat menghitung nilai standar deviasi, nilai mean, nilai maksimum dan minimum, dengan penjelasan bahwa setiap variabel data dianalisis terkait distribusi frekuensinya. Hasil dari analisis univariat ini disajikan dalam bentuk tabel yang disertai narasi. Selanjutnya data juga analisis secara bivariat dengan uji statistik korelasi Spearman bila datanya berdistribusi normal dan jika tidak berdistribusi normal maka digunakan uji Pearson sebagai uji alternatif dari korelasi Spearman. Sebelum melakukan uji korelasi, terlebih dilakukan uji One-Sample Kolgomorov Smirnov Test untuk mengetahui normalitas dari suatu distribusi data.

Analisis penelitian disajikan dalam bentuk tabel, grafik, dan narasi sehingga dapat memperjelas hasil penelitian. Hubungan antara variabel curah hujan suhu udara dengan kejadian DBD disimpulkan dengan membandingkan nilai signifikasi ( $p$-value) dan nilai $\alpha 0,05$, serta kekuatan hubungan dilihat berdasarkan nilai koefiesien korelasi (r) (Dahlan, 2011). 


\section{HASIL}

Distribusi frekuensi masing-masing variabel penelitian dilihat berdasarkan nilai standar deviasi, nilai mean, nilai maksimum dan minimum yang ditampilkan dalam bentuk tabel yang disertai dengan narasi. Sedangkan untuk melihat korelasi antara variabel bebas dengan variabel terikat ditampilkan dalam bentuk tabel koefisien korelasi dan grafik.

\section{Distribusi Frekuensi Kejadian DBD}

Distribusi frekuensi kejadian DBD per bulan di Kota Bau-Bau dari bulan Januari 2015 sampai dengan bulan Desember tahun 2019 ditampilkan dalam bentuk nilai standar deviasi, nilai mean, nilai maximum dan minimum. Kejadian DBD per bulan di Kota Bau-Bau menunjukkan tren yang dinamis dan fluktuatif selama 5 tahun pengamatan, yaitu mulai Januari tahun 2015 sampai dengan Desember tahun 2019. Kejadian DBD di Kota Bau-Bau hampir setiap bulannya selalu ada sepanjang tahun 2015 sampai dengan 2019, terkecuali pada tahun 2016 ada 8 bulan terjadi zero incidence DBD yaitu pada bulan Mei sampai dengan Desember dan tahun 2017 bulan Oktober sampai Desember serta tahun 2019 pada bulan Agustus dan Desember juga tidak ada kasus DBD. Kematian karena DBD terjadi pada tahun 2016, 2018 dan 2019. CFR pada tahun 2016 dan 2018 sebesar 1,0\% sedangan CFR pada tahun 2019 meningkat menjadi $1,3 \%$. Total kematian karena DBD di Kota Bau-Bau untuk periode pengamatan tahun 2015 sampai dengan 2019 dengan 4 kasus. Selengkapnya distribusi kejadian DBD di Kota Bau-Bau dari tahun 2015 sampai dengan tahun 2019 dapat dilihat pada tabel 1 berikut.

Tabel 1. Distribusi Frekuensi Kejadian DBD Per Bulan Tahun 2015-2019

\begin{tabular}{lccrr}
\hline & $\begin{array}{c}\text { Standar } \\
\text { Deviasi }\end{array}$ & Mean & Min. & Max. \\
\hline $\begin{array}{l}\text { Kejadian } \\
\text { DBD }\end{array}$ & 10.89622 & 8.4667 & 0 & 61 \\
\hline
\end{tabular}

Tabel 1 menunjukkan bahwa distribusi kejadian DBD di Kota Bau-Bau periode waktu tahun 2015 sampai dengan tahun 2019 terendah adalah 0 atau tidak ada kasus yang terjadi selam 8 bulan pada tahun 2016 yaitu pada bulan Mei sampai Desember dan selama 3 bulan pada tahun 2017 yaitu pada bulan oktober sampai dengan Desember 2017 serta pada bulan Agustus dan Desember tahun 2019. Sehingga terjadi sebanyak 13 bulan Zero Incidence Cases DBD selama periode tahun 2015 sampai dengan tahun 2019. Sedangkan kasus tertinggi adalah 61 kasus yang terjadi pada bulan Januari 2016. Rata-rata kejadian DBD per bulan selama periode tahun 2015 sampai dengan 2019 adalah 8 kasus.

\section{Diftribusi Frekuensi Curah Hujan}

Distribusi frekuensi curah hujan per bulan di Kota Bau-Bau dari bulan Januari 2015sampai dengan bulan Desember tahun 2019 ditampilkan dalam bentuk nilai standar deviasi, nilai mean, nilai maksimum dan minimum. Gambaran curah hujan per bulan di Kota Bau-Bau terjadi cukup dinamis sepanjang tahun 2015 sampai dengan tahun 2019. Kota Bau-Bau merupakan daerah dengan iklim tropis yang memiliki curah hujan yang cukup tinggi terutama pada musim penghujan. Sepanjang tahun 2015 sampai dengan 2019 curah hujan di Kota Bau-Bau cukup bervariasi. Namun demikian terdapat beberapa bulan dengan curah hujan yang sangat rendah bahkan sampai pada titik 0 (nol) yaitu terjadi pada bulan Agustus sampai dengan Oktober tahun 2015, dan bulan Agustus sampai dengan Oktober pada tahun 2018 serta bulan Agustus dan September 2019. Selengkapnya distribusi frekuensi curah hujan disajikan pada tabel 2 berikut.

Tabel 2. Distribusi Frekuensi Curah Hujan Per Bulan Tahun 2015-2019

\begin{tabular}{lccrc}
\hline & $\begin{array}{c}\text { Standar } \\
\text { Deviasi }\end{array}$ & Mean & Min. & Max. \\
\hline $\begin{array}{l}\text { Curah } \\
\text { hujan }\end{array}$ & 134.594 & 159,83 & 0 & 481.0 \\
\hline
\end{tabular}

Tabel 2 menunjukan bahwa rata-rata curah hujan per bulan periode Januari tahun 2015 sampai dengan Desember 2019 adalah 159,83mm, dan curah hujan minimum adalah $0 \mathrm{~mm}$ serta curah hujan maksimal adalah $481 \mathrm{~mm}$.

\section{Diftribusi Frekuensi Suhu Udara}

Distribusi frekuensi suhu udara per bulan di Kota Bau-Bau dari bulan Januari 2015sampai dengan bulan Desember tahun 2019 ditampilkan dalam bentuk nilai standar deviasi, nilai mean, nilai maksimum dan minimum. Tingkat suhu udara di wilayah Kota Bau-Bau cukup merata baik pada wilayah pesisir maupun pada wilayah pegunungan. Selengkapnya distribusi frekuensi curah hujan disajikan pada tabel 3 berikut. 
Tabel 3. Distribusi Frekuensi Suhu Udara Per Bulan Tahun 2015-2019

\begin{tabular}{ccccc}
\hline & $\begin{array}{c}\text { Standa } \\
\mathbf{r} \\
\text { Deviasi }\end{array}$ & Mean & Min. & Max \\
\hline Suhu Udara & 8,3109 & 80,75 & 62 & 98 \\
\hline
\end{tabular}

Tabel 3 menunjukan bahwa rata-rata suhu udara di Kota Bau-Bau per bulan periode Januari tahun 2015 sampai dengan Desember 2019 adalah $80,75 \%$, dan suhu udara minimum adalah $62 \%$ serta suhu udara makimal adalah $98 \%$.

\section{Hubungan Curah Hujan dengan Kejadian DBD}

Untuk mengetahui hubungan curah hujan dengan kejadian DBD dilakukan analisis bivariat dengan uji Spearman correlation (korelasi Spearman). Hasil analisis hubungan antara variabel curah hujan dengan kejadian DBD disajikan pada tabel 4 berikut.

Tabel 4. Hasil Analisis Hubungan Antara Curah Hujan dengan Kejadian DBD Tahun 2015-2019

\begin{tabular}{lcc}
\hline & \multicolumn{2}{c}{ Kejadian Demam Berdarah (DBD) } \\
\cline { 2 - 3 } & $\begin{array}{c}\text { Koefisien } \\
\text { Korelasi (r) }\end{array}$ & $\begin{array}{c}\text { Signifikansi } \\
(\boldsymbol{p} \text {-value })\end{array}$ \\
\hline Curah & 0,35 & 0,006 \\
Hujan & 0, & 0 \\
\hline
\end{tabular}

Tabel 4 menunjukkan bahwa berdasarkan hasil uji korelasi Spearman antara curah hujan dengan kejadian DBD diperoleh bahwa ada hubungan signifikan (bermakna) antara curah hujan dengan kejadian DBD ( $p$-value $=0,006)$ dengan kekuatan hubungan yang lemah $(r=0,35)$ dengan arah hubungan yang positif serta derajat hubungan yang sedang. Pola hubungaan antara variabel curah hujan dengan kejadian DBD di Kota Bau-Bau dari bulan Januari 2015-Desember 2019 disajikan dalam bentuk grafik pada gambar 1 .

\section{Grafik Hubungan Curah Hujan dengan Kejadian DBD}

Grafik hubungan antara curah hujan dengan kejadian DBD di Kota Bau-Bau dapat dilihat pada gambar 1 berikut.

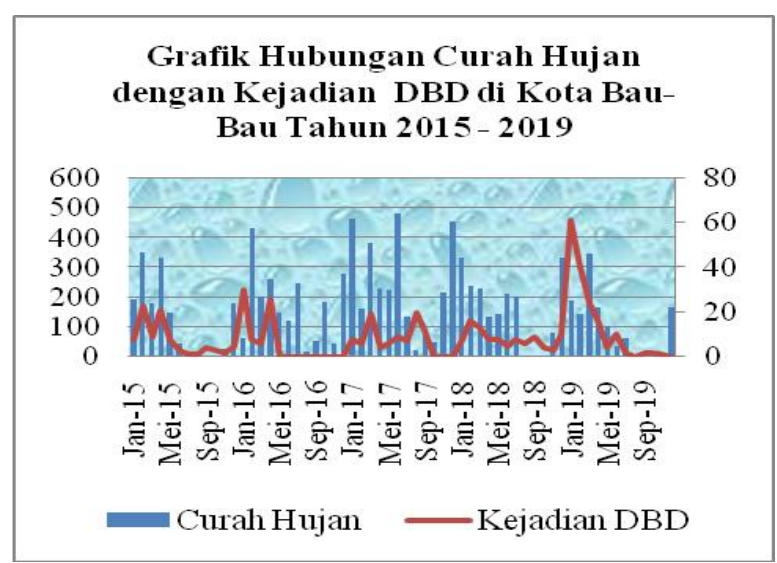

Gambar 1. Grafik Hubungan Curah Hujan Per Bulan dengan Kejadian DBD Tahun 2015-2019

Gambar 1 menunjukkan bahwa variabel yang dianalisis dengan uji korelasi Spearman adalaah curah hujan dan kejadian DBD di Kota Bau-Bau. Variabel kejadian DBD di tampilkan dalam bentuk grafik garis dan curah hujan ditampilkan dalam bentuk grafik batang. Dari gambar 1 tampak bahwa grafik fluktuatif antara curah hujan dan kejadian DBD tidak persis seirama. Penurunan kasus DBD sampai pada titik zero incidence tidak diikuti sepenuhnya oleh penurunan curah hujan sampai pada titik 0 , demikian pula sebaliknya. Akan tetapi terdapat satu titik dimana antara kasus DBD dan curah hujan ada pada titik 0 secara bersama-sama yaitu pada bulan Agustus 2019. Selain itu nampak pula bahwa pola kedua grafik pada kejadian DBD dan curah hujan pada gambar 1 menunjukkan bahwa banyak juga momentum dari pola grafik yang seirama sehingga dalam uji statistik dengan korelasi Spearman diperoleh hasil hubungan kedua variabel adalah sedang dengan arah yang positif dengan nilai $p$-value $=0,006$ dan $\mathrm{r}=0,35$.

\section{Hubungan Suhu Udara dengan Kejadian DBD}

Untuk mengetahui hubungan suhu udara dengan kejadian DBD dilakukan analisis bivariat dengan uji Spearman correlation (korelasi Spearman). Hasil analisis hubungan antara variabel curah hujan dengan kejadian DBD disajikan pada tabel 5 berikut.

Tabel 5. Hasil Analisis Hubungan antara Suhu Udara dengan Kejadian DBD Tahun 2015-2019

\begin{tabular}{lcc}
\hline & \multicolumn{2}{c}{ Kejadian Demam Berdarah (DBD) } \\
\cline { 2 - 3 } & $\begin{array}{c}\text { Koefisien } \\
\text { Korelasi (r) }\end{array}$ & $\begin{array}{c}\text { Signifikansi } \\
(\boldsymbol{p} \text {-value })\end{array}$ \\
\hline $\begin{array}{l}\text { Suhu } \\
\text { Udara }\end{array}$ & 0,576 & 0,000 \\
\hline
\end{tabular}


Tabel 5 menunjukkan bahwa berdasarkan hasil uji korelasi Spearman antara suhu udara dengan kejadian DBD diperoleh bahwa ada hubungan signifikan (bermakna) antara suhu udara dengan kejadian DBD ( $p$-value $=0,000$ ) dengan kekuatan hubungan yang kuat $(\mathrm{r}=0,576)$ dengan arah hubungan yang positif. Pola hubungaan antara variabel suhu udara dengan kejadian DBD di Kota Bau-Bau dari bulan Januari 2015-Desember 2019 disajikan dalam bentuk grafik pada gambar 2 .

\section{Grafik Hubungan Suhu Udara dengan kejadian DBD}

Grafik hubungan antara kelembaban udara dengan kejadian DBD di Kota Bau-Bau dapat dilihat pada gambar 2 berikut.

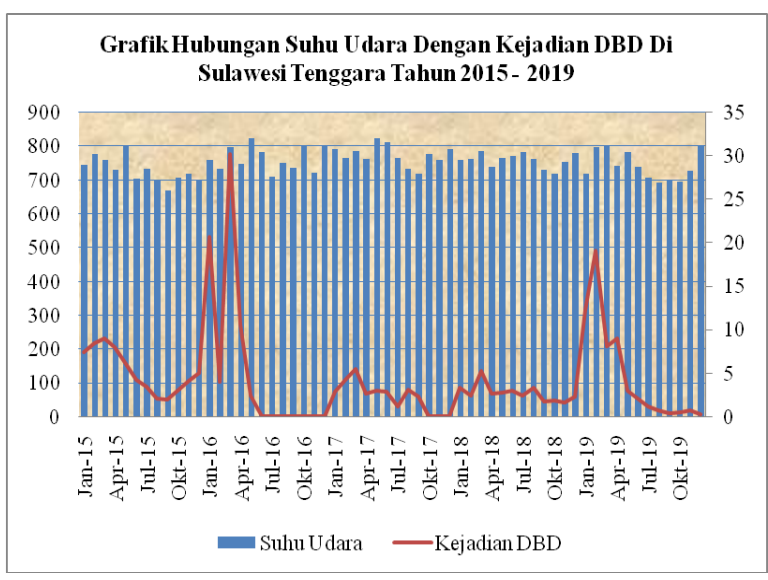

\section{Gambar 2. Grafik Hubungan Suhu dengan Kejadian DBD per Bulan Tahun 2015-2019}

Gambar 2 menunjukkan bahwa variabel yang dianalisis dengan uji korelasi Spearman adalah suhu udara dan kejadian DBD di Kota Bau- Bau. Variabel kejadian DBD di tampilkan dalam bentuk grafik garis dan suhu udara ditampilkan dalam bentuk grafik batang. Dari gambar 2 tampak bahwa tren kedua grafik suhu dan kejadian DBD sebagian besar persis seirama, sehingga dalam uji statistik dengan korelasi Spearman diperoleh hasil hubungan kedua variabel adalah kuat dengan arah yang positif dengan nilai $p$-value $=0,000$ dan $\mathrm{r}=0,576$.

\section{PEMBAHASAN}

\section{Hubungan Curah Hujan dengan Kejadian DBD}

Hujan adalah peristiwa sampainya air dalam bentuk cair maupun padat yang dicurahkan dari atmosfer ke permukaan bumi. Curah hujan yaitu jumlah air hujan yang turun pada suatu daerah dalam waktu tertentu. Alat untuk mengukur banyaknya curah hujan disebut rain gauge. Curah hujan diukur dalam harian, bulanan, dan tahunan. Curah hujan yang jatuh di wilayah Indonesia dipengaruhi oleh faktor seperti, bentuk medan atau topografi, arah lereng medan, arah angin yang sejajar dengan garis pantai, jarak perjalanan angin di atas medan datar (Regariana, 2005).

Kondisi rerata curah hujan per bulan di Kota Bau-Bau selama periode tahun 2015 sampai dengan 2019 adalah 159,83mm. Setiap milimeter $(\mathrm{mm})$ dalam satuan tersebut dimaksudkan dengan perhitungan $(1 \mathrm{~mm} \quad \mathrm{x} \quad 1 \mathrm{~m} \quad \mathrm{x} 1 \mathrm{~m})$, sehingga dihasilkan volume curah hujan per meter persegi adalah satu liter. Kondisi curah hujan jelas memengaruhi kehidupan nyamuk, utamanya terkait terbentuknya breeding places atau tempat perindukan. Menurut Suroso (2000) dalam Paramita \& Mukono (2017), curah hujan dapat menambah kepadatan populasi nyamuk. Seperti setiap milimeternya dapat menambah kepadatan nyamuk sejumlah 1 ekor. Namun jumlah curah hujan mencapai $140 \mathrm{~mm}$ dalam seminggu maka larva hanyut kemudian mati (Paramita dan Mukono, 2017).

Hasil penelitian ini menunjukkan bahwa variabel curah hujan per bulan memiliki hubungan dengan kejadian DBD per bulan di Kota Bau-Bau periode tahun 2015 sampai dengan 2019. Hubungan tersebut diperoleh dari analisis dengan uji Korelasi Spearman dengan hasil nilai signifikansi ( $p$-value) sebesar 0,006. Nilai signifikansi yang lebih kecil dari 0,05 menunjukkan bahwa variabel bebas memiliki hubungan dengan variabel terikat. Kemudian dapat diketahui keeratan atau kekuatan hubungan tersebut dengan melihat nilai pada koefisien korelasi (r) yaitu sebesar 0,35 dengan arah hubungan yang positif. Makna dari hubungan yang signifikan atau bermakna dan kekuatan hubungan sebesar 0,35 dengan arah hubungan yang positif ini adalah semakin tinggi jumlah curah hujan di Kota Bau-Bau, maka kejadian DBD juga meningkat. Semua hasil analisis tersebut hanya berlaku untuk periode atau selama 5 tahun yaitu pada tahun 2015 sampai dengan tahun 2019 di Kota Bau-Bau.

Hasil penelitian ini didukung oleh penelitian yang dilakukan oleh Arcari, et al. (2007) yang melakukan penelitian di Indonesia untuk melihat hubungan iklim dengan peningkatan kasus demam dengue (dengue fever) dan demam berdarah dengue (DHF) yang menemukan bahwa ada korelasi iklim (curah hujan) dengan kejadian DBD dengan nilai $p$ - 
value $=0,01$ dan kategori kekuatan hubungan adalah sedang $(\mathrm{r}=0,43)$. Dalam penelitian Aracari, et al. menemukan bahwa peningkatan curah hujan per bulan berhubungan dengan intesitas gigitan vektor dan insiden DBD (Arcari P, Tapper and Plueller, S, 2007).

Penelitian lain yang juga sesuai dengan hasil penelitian ini adalah penelitian yang dilakukan di Kabupaten Pasuruan Jawa Timur oleh Ali dan Ma'rufi pada tahun 2008 menemukan bahwa ada hubungan yang signifikan antara curah hujan perbulan dan periode hujan per hari dengan peningkatan kasus DBD di Kabupaten Pasuruan dengan nilai $\mathrm{p}$ masing-masing adalah 0,000 dengan kekuatan hubungan yang sangat kuat (Ali dan Ma'Rufi, 2018).

Adanya hubungan yang signifikan antara faktor lingkungan khususnya curah hujan dengan kejadian DBD dari analisis epidemiologi lingkungan dan kejadian suatu penyakit khususnya penyakit bersumber vektor (Aedis Aegypti) dapat diakibatkan karena dengan curah hujan yang tinggi dapat meningkatkan potensi terbentuknya breeding places atau tempat perindukan vektor atau nyamuk Aedis Aegypti atau Aedis Albopictus yang dapat mendukung terjadinya peningkatan populasi vektor sehingga terjadi tingkat kepadatan vektor penyebar virus dengue yang pada akhirnya akan menyebabkan risiko terjadinya kontak antara vektor penular DBD dengan manusia. Dengan demikian vektor yang sudah mengandung virus infeksius akan menularkan ke orang baru yang belum terifeksi dan terus terjadi penularan apa bila tidak dilakukan pencegahan dan pengendalian baik dari sisi pencegahan kontak ataupun pengendalian vektornya. Hal inilah yang menyebabkan terjadinya peningkatan kasus DBD jika terjadi peningkatan curah hujan pada suatu wilayah khususnya wilayah yang endemis DBD.

\section{Hubungan Suhu Udara dengan Kejadian DBD}

Suhu atau temperatur udara adalah derajat panas dari aktivitas molekul dalam atmosfer. Suhu merupakan karakter yang dimiliki oleh suatu benda yang berhubungan dengan panas dan energi. Suhu udara akan berfluaktuatif dengan nyata setiap peride 24 jam. Fluktuatif ini berkaitan erat dengan proses pertukaran energi yang berlangsung di atmosfer. Fluaktuatif suhu akan terganggu jika terjadi turbulensi udara atau pergerakan massa udara menjadi sangat aktif, misalnya pada kondisi kecepatan angin tinggi. Jika pergerakan massa udara tersebut tersebut melibatkan seluruh lapisan udara dekat permukaan, maka suhu udara pada permukaan tersebut relatif homogeny (Heriyani, 2019).

Suhu udara pada lingkungan terbuka berbeda dengan udara pada gedung, demikian juga suhu lingkungan seperti diladang dan disawah berbeda. Pengukuran suhu udara hanya memperoleh satu nialai yang menyatakan nilai rata-rata atmosfer. Ada dua skala pengukuran suhu udara lingkungan yang sering digunakan yaitu skala Farenheit yang dipakai di negara Inggris dan Celcius yang dipakai oleh sebagian besar negara di dunia (Heriyani, 2019).

Hasil penelitian ini menunjukkan bahwa variabel suhu udara lingkungan per bulan memiliki hubungan yang tidak signifikan dengan kejadian DBD per bulan di Sulawesi Tenggara periode tahun 2015 sampai dengan 2019. Analisis hubungan kedua variabel tersebut dengan uji korelasi Spearman diperoleh hasil nilai signifikansi ( $p$-value) sebesar 0,61. Nilai signifikansi yang lebih besar dari 0,05 menunjukkan bahwa variabel bebas hubungan dengan variabel terikat tidak signifikan atau tidak bermakna. Namun demikian terdapat korelasi linier antara suhu udara dengan kejadian DBD sebesar 0,44. Kondisi ini dapat dijelaskan bahwa suhu udara lingkungan dengan kejadian DBD tidak memiliki hubungan kausaltik atau hubungan sebab-akibat, akan tetapik kedua variabel yaitu suhu udara lingkungan dan kejadian DBD memiliki korelasi. Hal ini dibukitiak dengan hasil uji korelasi Spearman yang ditemukan yaitu nilai $p$-value $=0,61$ dan nilai $r=0,44$. Artinya bahwa peningkatan suhu udara lingkungan tidak secara pasti akan menyebabkan peningkatan kasus DBD. Hal ini dapat terlihat jelas pada grafik hubungan antara suhu udara dengan kejadian DBD (gambar 3). Fluaktuatif antara kedua variabel ini sangat tidak seirama. Ini juga disebakan karena kisaran suhu dalam satu bulan pengamatan cenderung sama, tidak ada perubahan yang berarti sepanjang periode waktu pengamatan mulai 2015 sampai 2019.

Penelitian ini didukung oleh penelitian sejenis yang di lakukan oleh Nitatpattana, et al. (2007) di Thailand yang meneliti untuk mengugi adanya korelasi dan pengaruh suhu permukaan dan suhu dengan kejadian DBD di sebuah pualau dengan suhu yang cukup tinggi. Hasil penelitian Nitatpattana, et al, (2007) menunjukkan bahwa ada korelasi antara suhu udara dan permukaan bumi dengan insidensi DBD dengan nilai $p$ value $<0,05$. 


\section{SIMPULAN}

Penyakit DBD merupakan salah satu masalah kesehatan masyarakat yang serius di

\section{DAFTAR PUSTAKA}

Ali, K. and Ma'Rufi, I. (2018). The relationship between rainfall and dengue hemorrhagic fever incidence during 2009-2013 (Case study at Grati and Tutur Sub-district, Pasuruan, Indonesia). IOP Conference Series: Earth and Environmental Science, 200(1). doi: 10.1088/17551315/200/1/012031.

Arcari P, Tapper, N. and P. S. (2007). Regional variability in relationships between climate and dengue/DHF in Indonesia. Singapore Journal of Tropical Geography, 28(3), 251-272. https://doi.org/10.1111/j.14679493.2007.00300.x.

Banu, S. et al. (2011). Dengue transmission in the Asia-Pacific region: Impact of climate change and socio-environmental factors. Tropical Medicine and International Health, 16(5), 598-607. doi: 10.1111/j.1365-3156.2011.02734.x.

Dahlan, M. S. (2011) Statistik Untuk Kedokteran dan Kesehatan. Jakarta: Salemba Medika.

Halstead, S. B. and Deen, J. (2002). The future of dengue vaccines. Lancet, 360(9341), 12431245. doi: 10.1016/S0140-6736(02)11276-1.

Heriyani, F. (2019). Correlation Between Air Temperature and Humidity. Berkala Kedokteran, 15(1), 1-6.

Iriani, Y. (2016). Hubungan antara Curah Hujan dan Peningkatan Kasus Demam Berdarah Dengue Anak di Kota Palembang. Sari Pediatri, 13(6), 378. doi: 10.14238/sp13.6.2012.378-83.

Mishra, R. and Kumar, P. (2011). A study on outbreak of dengue from Bihar, Indiaestablishing new foci, attributable to climatic changes. Journal of Public Health and Epidemiology, 3(11), 489-502. http://www.academicjournals.org/JPHE/P
Kota Bau-Bau Sulawesi Tenggara yang berhubungan dengan faktor iklim yaitu curah hujan dan suhu udara.

DF/pdf2011/16\%0ANovember/Mishra\%0 Aet\%0Aal.pdf.

Nitatpattana, N. et al. (2007). Potential association of dengue hemorrhagic fever incidence and remote senses land surface temperature, Thailand, 1998. Southeast Asian Journal of Tropical Medicine and Public Health, 38(3), 427-433.

Paramita, R. M., \& Mukono, J. (2017). Hubungan kelembapan udara dan curah hujan dengan kejadian demam berdarah dengue di Puskesmas Gunung Anyar 20102016. The Indonesian Journal of Public Health, 12(2), 202-212.

Regariana, C. M. (2005). Atmosfer (Cuaca dan Iklim). Solo: Tiga Serangkai.

Scott, T. W. (2009). Dengue. Encyclopedia of Insects, pp. 257-259. doi: 10.1016/B978-012-374144-8.00078-3.

Sultra, D. K. P. (2020). Laporan Bidang Pencegahan Dan Pengendalaian Penyakit Dinas Kesehatan Provinsi Sulawesi Tenggara. Dinas Kesehatan Provinsi Sulawesi Tenggara.

Taylor, A. N., Cullinan, P., Blanc, P., \& Pickering, A. (2016). Parkes' Occupational Lung Disorders. CRC Press. doi: 10.1201/9781315381848.

WHO. (2011). Comprehensive guidelines for prevention and control of dengue and dengue haemorrhagic fever, WHO Regional Publication SEARO. World Health Organization, Regional Office for South-East Asia. doi: 10.1017/CBO9781107415324.004.

Zambrano, L. I. et al. (2012). Potential impacts of climate variability on Dengue Hemorrhagic Fever in Honduras, 2010', Tropical Biomedicine, 29(4), 499-507. 